\title{
Az inzulinpumpa és a folyamatos cukormonitorozás használatának terjedési dinamikája és költségei a diabeteses gyermekellátás tükrében
}

\section{Cserháti Edit dr.}

\begin{abstract}
Osszefoglalás
A dolgozat az egészségpénztár nyilvános adatbázisának elemzésével mutatja be az inzulinpumpa használatának hazai elterjedését az elmúlt 10 évben. Az amortizáció figyelembevételével kalkulálja a használatban lévö inzulinpumpák és újonnan belépö inzulinpumpa-használók számát, felveti a nem egyforma hozzáférhetőség lehetöségét. Azonos adatbázis használatával bemutatja a szöveti cukormonitorozás finanszirozásának aktuális, országos helyzetét, kalkulálja egészségpénztári költségeit, valamint egy 1-es típusú cukorbeteg gyermek ellátásának társadalmi költségeihez viszonyitja a szöveti cukormonitorozás finanszirozása által okozott többletköltséget. Az évi 700 e Ft-ot megközelitö bruttó kiadás az egyedi méltányossággal finanszirozott, havi 5 doboz tesztcsík használatához viszonyítva költséghatékony, kb. évi 150 e Ft-os, azaz 7,5\%-os költségnövekedést okoz, ami a jobb anyagcserekontrollra alapozva a cukorbetegek egészségébe befektetett beruházásként fogadható el.
\end{abstract}

Kulcsszavak: inzulinpumpa, szöveti cukormonitorozás, költséghatékonyság, egészségpénztári kiadás

\section{The dynamics of insulinpump and CGM usage in Hungary, costs of the reimbursement}

Summary: Analysing the open database of the Hungarian National Health Insurance Fund the study presents the spread of insulinpump usage in the past 10 years. Considering the amortisation calculates the number of currently used insulinpumps and new insulinpump users and raises the possibility of unequal access to this treatment type. Using the same database it presents the current national financial aspects of interstitial glucose monitoring: calculates its health insurance costs and compares its extra costs to the social costs of a child with type 1 diabetes. The yearly nearly gross 700 thousand Ft (HUF) expense of interstitial glucose monitoring is cost effective compared to the individually authorised and financed use of monthly 5 boxes of blood glucometer test strips resulting in about 150 thousand HUFs - equaling $7,5 \%$ extra cost which considering the better metabolic control can be accepted as an investment into the health of diabetic patients.

Keywords: insulinpump, continuous glucose monitoring, cost-effectiveness, health insurance cost

Rövidítés:

SMBG: vércukor-önellenörzés (self monitoring of blood glucose)

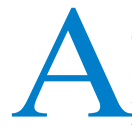

gyermekdiabetológiában fokozatosan itthon is meghonosodik az inzulinpumpa-kezelés, miközben a szöveti cukormonitorozást az egyedi méltányossági igénylés nehezíti. A mindennapi munka során ki-ki saját betegeivel, illetve a gondozócentrum adataival 
találkozik. Alig van rálátásunk az országos helyzetre, ezen a nemrég bevezetett inzulinpumpa-regiszter adatai hozhatnak változást. Az új technológiák bevezetésének nemcsak az aktuális helyzete, hanem a dinamikája is figyelemre méltó.

Ha megnézzük, hogy évente hány inzulinpumpa beszerzését támogatta a hazai egészségbiztosító (korábban Országos Egészségbiztosítási Pénztár OEP, új nevén a Nemzeti Egészségbiztosítási Alapkezelő - NEAK), azt látjuk, hogy a gyors indulás mellett az utóbbi három évben már nem volt érdemi emelkedés a finanszírozott pumpabeszerzések számában (1. ábra). A közzétett adatok ${ }^{1}$ a finanszírozott beszerzésű pumpák számát adják meg, ezek egy része azonban a megújított pumpakezelésre fordítódik. Figyelembe véve, hogy egy pumpa garanciája négy évig tart, illetve hogy a pumpakezelés - megfelelő anyagcserekontroll mellett - leghamarabb négy év után újítható meg és feltételezve, hogy ez a betegek számára el is érhető, statisztikailag négy év elteltével a NEAK nem csupán az új inzulinpumpa felhelyezését, hanem igény szerint a megújított pumpakezelést is finanszírozza. Ha a négy évvel korábban felhelyezett pumpák számával csökkentjük az évente felhelyezésre kerülő inzulinpumpák számát, megközelítő adatot kapunk az inzulinpumpa-kezelésbe újonnan belépők számáról (2. ábra).

A képet árnyalja, hogy a gyermekek növekedésével a korábban kiemelten támogatott pumpakezelés megújítása megjelenhet új belépőként a felnőttek között is, továbbá hogy van, aki nem kívánja, vagy a rossz anyagcserekontroll miatt nem tudja megújítani, esetleg a magas önrész (felnőtteknél közel 200 e Ft) miatt garanciaidőn túl cseréli az inzulinpumpát. Mindez gátolja a precíz becslést, ugyanakkor a statisztika azt mutatja, hogy az új belépők száma fokozatosan csökken. A 2. ábrán feltüntetett adatok négyévenkénti pumpacsere mellett lennének valósak, a garanciaidőn túli pumpacsere növeli a használatban lévő pumpák számát. Ötévenkénti cserével számolva 2019 elejére a használatban lévő inzulinpumpák száma megközelíthette a $3000 \mathrm{db}$-ot.

Ahogy arról már a Magyar Diabetes Társaság és a Magyar Gyermekgyógyász Társaság közös Gyermekdiabetes-szekciója 2018 őszén szervezett ülésén is beszámoltam, jelenleg közel 1200 kiemelt támogatással finanszírozott inzulinpumpa van használatban - feltételezve, hogy a kis önköltség mellett ezek a pumpák négyévente cserére kerülnek. Ezeket a pumpákat olyan gyermekek és fiatalok használják, akik vagy 18 év alattiak, vagy 24 év alatti nappali tagozatos hallgatók. Összevetve az 1-es típusú cukorbetegség miatt gondozott gyermekek számával, körülbelül minden 4.-5. kiskorú részesül pumpakezelésben, ami a pumpakezelés hozzáférhetőségét bizonyítja. Ugyanakkor a még nem általános inzulinpumpa-használat, illetve a diabetes gyermekkori incidenciájának növekedése mellett okkal számíthatnánk arra, hogy évről évre egyre több inzulinpumpa kerül újonnan felhelyezésre. A NEAK adatai azonban nem ezt tükrözik (2. ábra).

A stagnálás magyarázata nem tisztázott. Lehet az oka területi hozzáférési nehézség (nehezen megközelíthető pumpacentrumok), az egészségügy túlterheltsége. Lehet a komplikált dokumentáció miatti orvosi érdektelenség, vagy hogy a beteg anyagi helyzete nem engedi meg az inzulinpumpa használatát, esetleg nem szeretne inzulinpumpát használni stb. Az évente újonnan felhelyezett inzulinpumpák számának alakulása felveti a kérdést, vajon betegeink számára egyformán hozzáférhető-e a pumpakezelés az ország területén, tud-e a NEAK azonos lehetőséget biztosítani az ország különböző régióiban élő cukorbetegeknek a jobb életminőséghez?

Napi munkánk során nincs olyan gondozási nap, amikor legalább egy olyan beteggel ne találkoznánk, aki érdeklődik a szöveti cukormonitorozás lehetősége felől, vagy éppen már szöveti cukormonitor használó. Több esetben látjuk, hogy azok a családok, amelyek nem engedhetik meg maguknak a szöveti cukormonitor folyamatos használatát, a gyermek következő, akut betegségére tartalékolják az utolsó, még felhelyezhető szenzort, és az akut infekció során, nagyobb anyagcsere-biztonságra törekedve használják azt fel.

A cukorbetegség kezelésének költséghatékonysági megítélésére világszerte számos közgazdasági modellt dolgoztak ki, amelyek alapját nagyszabású tanulmányok képezik. Az egészségügyi tanulmányok adatainak számítógépes felhasználásával, az aktuális anyagcserehelyzet tanulmányozásával képesek a cukorbetegség jövőbeni lefolyását modellezni, kalkulálni a szövődmények várható megjelenését egy-egy kezelési eljárás mellett, illetve 


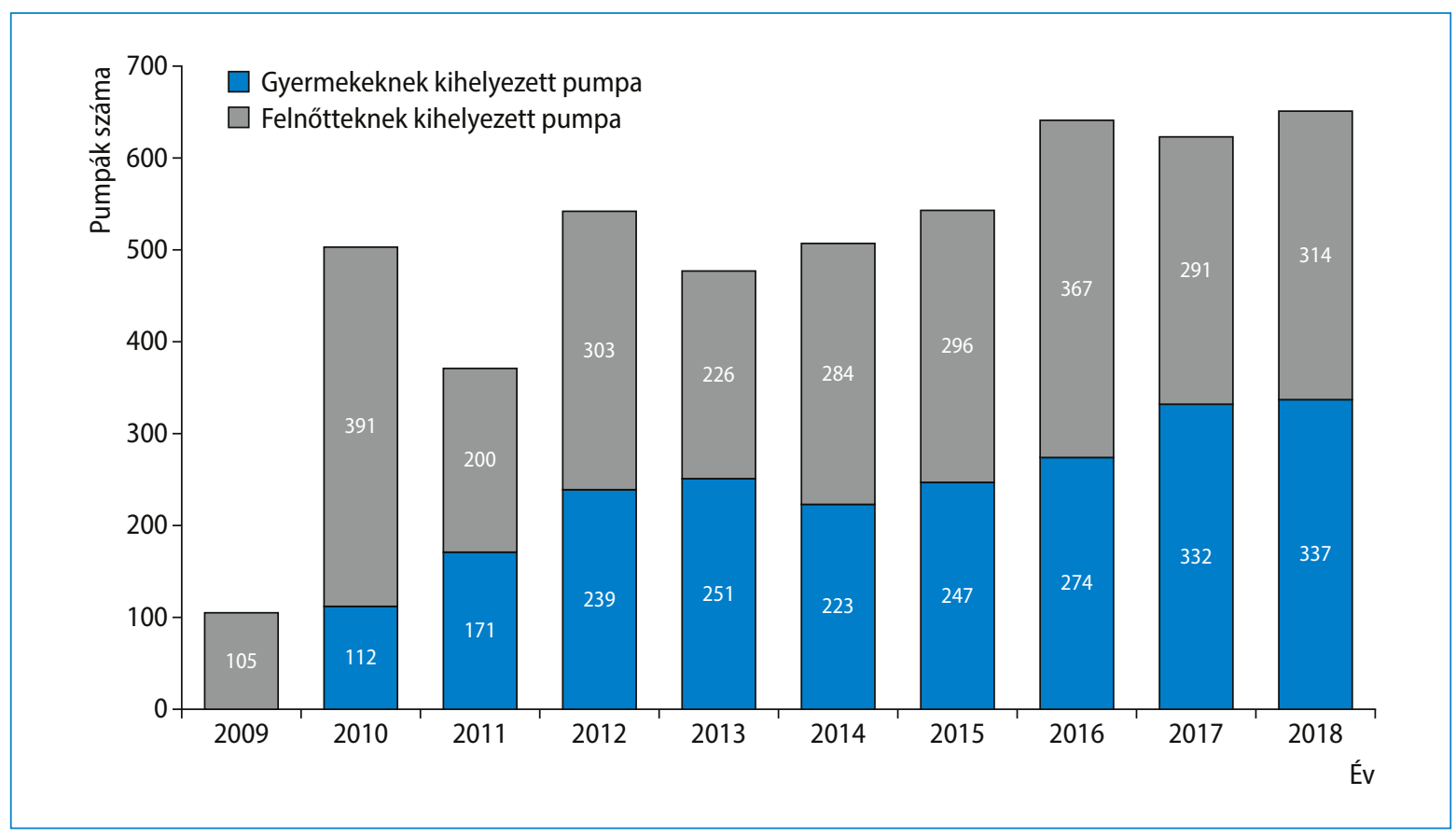

1. ábra. A Magyarországon évente felhelyezett inzulinpumpák száma

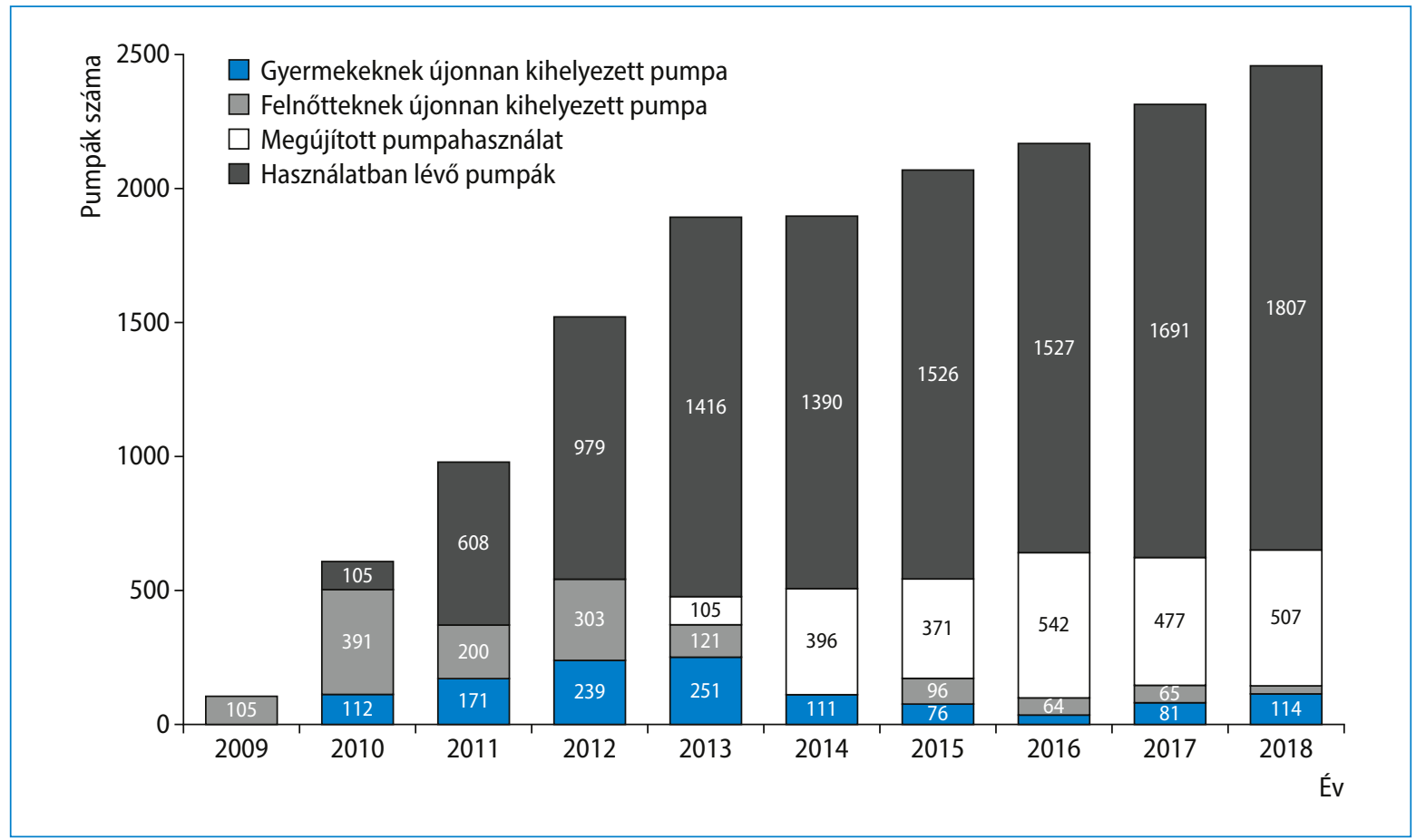

2. ábra. A használatban lévő inzulinpumpák megoszlása, évenkénti bontásban ${ }^{1}$ 
- a szövődmények függvényében - a várható költségek alakulását.

Ilyen modell például a Yale Egyetemen több mint 20 évvel ezelőtt a Center for Outcomes Research \& Evaluation munkacsoport által megalkotott CORE Diabetes Model. A szimulációs modell az 1-es és 2-es típusú cukorbetegség kezelése során felmerülő költségek figyelembevételével kalkulálja a betegség hosszú távú kimenetelét. ${ }^{2}$ Így nem csupán egy adott kezelés hatékonyságának előrejelzésére, hanem a várható költségek kiszámítására is képes. Így lehetővé teszi a cukorbetegség költség-hatékonyságának megítélését, valamint a különböző típusú inzulinkezeléseknek az anyagcserekontroll függvényében történő összehasonlítását. A szimulációhoz a DCCT és az UKPDS tanulmányok retrospektív adatait használták fel, és nem egészen 15 éves követéssel egészítették ki. Az így nyert kalkulációt független bírálat során hitelesnek találták mind az 1-es, mind a 2-es típusú cukorbetegség 30 éves kimenetelének becslésére.

Az ilyen és hasonló szimulációkkal számolt tanulmányok alapozhatták meg napjainkra számos környező európai országban azt a döntést, amely alapján a szöveti cukormonitorozás az 1-es típusú cukorbetegségben egészségbiztosítási támogatást élvez. Angliában 2015-ben, Németországban 2016-ban indult meg a szöveti cukormonitorozás egészségpénztári finanszírozása. A Diab Technol

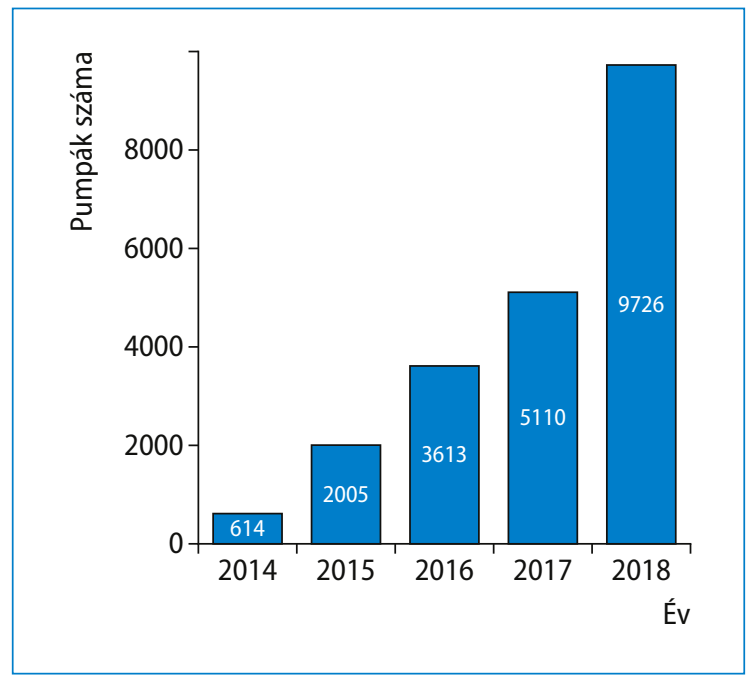

3. ábra. A hazánkban finanszírozott inzulinpumpák száma évenkénti bontásban ${ }^{7}$
Ther 2017. júniusban megjelent számában tételes beszámoló olvasható a svéd, norvég, francia, svájci, spanyol, belga, szlovén, holland, cseh és szlovák egészségpénztári finanszírozás feltételeiről. ${ }^{3}$ Továbbá 2018 szeptemberétől már Romániában is hozzáférhetővé vált a szöveti cukormonitorozás finanszírozott használata. A felsorolt országok gazdasági helyzete igen különböző, ami valószínűleg azt jelenti, hogy ezekben az államokban akár a szakmai, akár a betegjogi szervezetek - vagy éppen ezek karöltve - hatékonyabban tudtak fellépni a betegérdekek képviseletében, mint ahogy az jelenleg Magyarországon történik.

A 3. ábra továbbra is a NEAK adataira ${ }^{1}$ alapozva mutatja be az elmúlt években egyedi támogatással felhelyezett szenzorok számát. Bár az egyedi támogatás mértékét igényenként különböző százalékban szabja meg a pénztár, a finanszírozás mértéke a nyilvános adatbázisban nem elkülöníthető.

\section{Hogyan viszonyul a szöveti cukorszint- monitorozás (CGM) költsége az inzulinpumpa-kezelés árához?}

Amikor a NEAK egy évben egy betegnek az 52 hétből 48 hétre ad szenzorár-támogatást, ennek a költsége egy betegre átlagosan: $48 \times 9280=445440 \mathrm{Ft}$, azaz majdnem félmillió forint, amit a gyártó által javasolt kalibrációhoz szükséges tesztcsíkigény tovább drágít. Napi 4 vércukormérés mellett a vércukor-önellenőrzésre fordított éves összeg a vércukormérő amortizációjával kiegészítve közel 700 e Ft (1. táblázat). Így valóban luxusnak tűnhet a CGM használata. Érdemes azonban ezt a

\section{1. táblázat. A CGM segédeszközeinek finanszírozá- sa 1 évre}

\begin{tabular}{|c|c|c|c|} 
& Támogatás & $\begin{array}{c}\text { Egy évre } \\
\text { támogatott } \\
\text { mennyiség }\end{array}$ & Összesen \\
\hline $\begin{array}{c}\text { Vércukormérő } \\
\text { készülék }\end{array}$ & $3700 \mathrm{Ft} / \mathrm{db}$ & $1 / 6 \mathrm{db}$ & $617 \mathrm{Ft}$ \\
\hline $\begin{array}{c}\text { Tesztcsík } \\
(\mathbf{5 0} \mathrm{db} / \text { doboz })\end{array}$ & $\begin{array}{c}8360 \mathrm{Ft} / \\
\text { doboz }\end{array}$ & $30 \mathrm{doboz}$ & $250800 \mathrm{Ft}$ \\
\hline Enlite szenzor & $9280 \mathrm{Ft} / \mathrm{db}$ & $48 \mathrm{db}$ & $445440 \mathrm{Ft}$ \\
\hline Összesen & & & $696857 \mathrm{Ft}$ \\
\hline
\end{tabular}




\begin{tabular}{|c|c|c|}
\hline \multicolumn{2}{|c|}{$\begin{array}{l}\text { Pumpa + vércukor-önellenőrzés } \\
\text { egyedi méltányossággal }\end{array}$} & \multirow{2}{*}{$\begin{array}{c}\begin{array}{c}\text { Pumpa + CGM } \\
\text { (szenzor) }\end{array} \\
11452 \mathrm{Ft}\end{array}$} \\
\hline $11452 \mathrm{Ft}$ & Járóbeteg-ellátás finanszírozása & \\
\hline $11676 \mathrm{Ft}$ & $\begin{array}{c}\text { Laborvizsgálat dija } \\
\text { | }\end{array}$ & $11676 \mathrm{Ft}$ \\
\hline $292444 \mathrm{Ft}$ & $\begin{array}{l}\text { Fekvőbeteg-ellátás finanszírozása } \\
+22,5 \%\end{array}$ & $283733 \mathrm{Ft}$ \\
\hline $49275 \mathrm{Ft}$ & $\begin{array}{l}\text { Szülói kórházi ellátás és táppénz } \\
\qquad+11,11 \%\end{array}$ & $44348 \mathrm{Ft}$ \\
\hline $70189 \mathrm{Ft}$ & Gyógyszerár-támogatás & $70189 \mathrm{Ft}$ \\
\hline $779961 \mathrm{Ft}$ & Gyógyászati segédeszköz - inzulinkezelés & $779961 \mathrm{Ft}$ \\
\hline $486557 \mathrm{Ft}$ & $\begin{array}{r}\text { Gyógyászati segédeszköz - vércukor/szöveti cukor önellenőrzés } \\
\qquad+43,22 \%\end{array}$ & $696857 \mathrm{Ft}$ \\
\hline $295200 \mathrm{Ft}$ & Emelt összegű családi pótlék & $295200 \mathrm{Ft}$ \\
\hline $30000 \mathrm{Ft}$ & Közgyógyellátás & $30000 \mathrm{Ft}$ \\
\hline $2026754 \mathrm{Ft}$ & Összesen & $2178416 \mathrm{Ft}$ \\
\hline
\end{tabular}

4. ábra. A pumpakezelés és járulékos költségei egy 9 éves gyermek példáján ${ }^{7}$

költséget az inzulinpumpa-kezeléssel végzett cukorbetegség-gondozás társadalmi bekerülési költségéhez viszonyítani.

Amint már utaltunk rá, a NEAK forgalmazási adatai az inzulinpumpa elterjedésében ismeretlen eredetủ gátra utalnak. A pumpahasználat azonban az egészségpénztár által finanszírozott ellátás, aminek elérését ma már nem nehezíti egyedi méltányossági kérelem. Az 1-es típusú cukorbetegség éves társadalmi költségeinek kiszámítása egyénenként különböző eredményt hoz, figyelembe véve az életkort, az inzulinigényt és az anyagcsere-stabilitást.

Egy 9 éves gyermek ellátása során például a következő költségek merülnek fel: járó- és fekvőbeteg-ellátás, laboratóriumi vizsgálat, szülői táppénz, szülői kórházi ellátás, családi pótlék, közgyógyellátás, gyógyszerár-támogatás, az inzulinkezelés és a cukoranyagcsere-önellenőrzés eszközeinek ártámogatása (4. ábra). A kalkulációban az egyedi méltányossági kérelemmel kiegészített tesztcsík-használatot vettem figyelembe a jobb cukoranyagcsere-kontroll eléréséhez. Így a havi 5 doboz tesztcsíkot használó betegek körében a CGM-re váltás - a kisebb vércukormérőcsík-felhasználás, illetve az alacsonyabb akut hospitalizációs igény árkülönbözete miatt - évi 151660 Ft költségnövekedést okoz, ami a pumpakezelés összköltségének mindössze 7,5\%-os emelkedését jelenti (4. ábra). 
A szürkeimporttal elérhető, magyarországi háttérszolgáltatással nem rendelkező, flash rendszerű szöveti cukormonitorozás használata éves szinten egy betegnek több mint félmillió forint, az egészségpénztár által nem támogatott kiadást okoz. Terjedése felhívja a figyelmet a szöveti cukormonitorozás iránti igény növekedésére. A finanszírozás megteremtése évtizedes távlatokban új piaci szereplők belépésével versenyhelyzetet teremthet, ami a költségekre jótékony hatású lehet, ugyanakkor a CGM használatával megvalósuló jobb anyagcserekontroll a szövődmények későbbi megjelenésével kecsegtet.

A költségek számszerűsítése megerősíti azt az igényt, hogy a CGM használata egészségpénztári finanszírozással Magyarországon is elérhetővé váljon. A jó együttműködési készségű, egészségük megőrzésében érdekelt betegeknél a CGM finanszírozása költséghatékony, célszerü, az egészségbe való befektetésként fogadható el.
Irodalom

1. Nemzeti Egészségbiztositási Alapkezeló: Gyógyászati segédeszköz forgalmi adatok http://www.neak.gov.hu/felso_menu/szakmai_oldalak/publikus_ forgalmi_adatok/gyse_forgalmi_adatok

2. Palmer AJ, Roze $S$, Valentine WJ, Minshall ME, Foos V, Lurati FM, et al.: The CORE diabetes model: projecting longterm clinical outcomes, costs and costeffectiveness of interventions in diabetes mellitus (types 1 and 2) to support clinical and reimbursement decision-making. Curr Med Res Opin 2004; 20(Suppl 1): S5-S26. doi:10.1185/030079904X1980

3. Graham C: Continuous glucose monitoring and global reimbursement: an update. Diabetes Techn Ther 2017; 19(Suppl. 3): S60-S66. doi:10.1089/dia.2017.0096

Közlésre érkezett: 2019, április 17.

Közlésre elfogadva: 2019. május 16.

A szerzö levelezési címe:

\section{Dr. Cserháti Edit}

Pest Megyei Flór Ferenc Kórház, Csecsemő- és Gyermekosztály

2143 Kistarcsa, Semmelweis tér 1.

E-mail: cserhati.edit@gmail.com 